\title{
ROS and diseases: role in metabolism and energy supply
}

\author{
Shenshu Yang ${ }^{1} \mathbb{D} \cdot$ Gaojian Lian ${ }^{1}$
}

Received: 14 July 2019 / Accepted: 30 November 2019 / Published online: 7 December 2019

○) Springer Science+Business Media, LLC, part of Springer Nature 2019

\begin{abstract}
Researches dedicated to reactive oxygen species (ROS) had been performed for decades, yet the outcomes remain controversial. With the relentless effort of studies, researchers have explored the role of ROS in biosystem and various diseases. ROS are beneficial for biosystem presenting as signalling molecules and enhancing immunologic defence. However, they also have harmful effects such as causing tissue and organ damages. The results are controversial in studies focusing on ROS and ROS-related diseases by regulating ROS with inhibitors or promotors. These competing results hindered the process for further investigation of the specific mechanisms lying behind. The opinions presented in this review interpret the researches of ROS from a different dimension that might explain the competing results of ROS introduced so far from a broader perspective. This review brings a different thinking to researchers, with the neglected features and potentials of ROS, to relate their works with ROS and to explore the mechanisms between their subject and ROS.
\end{abstract}

Keywords ROS $\cdot$ Pathology $\cdot$ Diseases $\cdot$ Metabolism $\cdot$ Homeostasis

\section{Introduction}

ROS are a set of unstable molecules including hydrogen peroxide $\left(\mathrm{H}_{2} \mathrm{O}_{2}\right)$, hydroxyl radical $\left(\mathrm{OH}^{-}\right)$, singlet oxygen $\left({ }^{1} \mathrm{O}_{2}\right)$ and superoxide $\left(\mathrm{O}_{2}^{-}\right)$that are produced by all kinds of cells [1]. The comprehensive distribution of ROS may grant them with a fundamental role in biosystem. Although ROS play an important role in pathogen resistance and cellular signalling, they are also broadly recognized as harmful reactive particles to cell as they damage intracellular proteins, lipids and nucleic acids. It usually appears in pathological processes when they are not scavenged on time [2]. The essence that ROS are produced in energy demanding conditions where vigorous metabolism is in demand shall not be neglected. The pathogenic role of ROS in self-damage and the beneficial role in the immune system may be due to the requirement of energy supply. In these conditions, excessively produced ROS bring about oxidative damage to body and pathogens. ROS are widely involved in basic mechanisms

Shenshu Yang

517691576@qq.com

Gaojian Lian

714237626@qq.com

1 Hengyang Medical School, University of South China, Hengyang City, Hunan Province 421001, China and pathways. They not only impair cells and tissues with oxidative damage, but also play an important role in many homeostasis processes involving metabolism, immunity, growth and differentiation [3]. Researchers have been regarding ROS as byproducts and exploring their effects on organisms, but the fundamental features of ROS might illuminate their role in pathologies and biomechanisms.

\section{Generation of ROS}

Mitochondrial respiratory chain is one of the major sources of cellular ROS. ATP synthesis produces ROS during normal oxygen metabolism. Thus, ROS are regarded as byproducts during energy perfusion to cell activities in most cases. The primary function of NADPH oxidase (NOX) enzymes is the generation of ROS [1]. Belonging to the NOX family, activated NOX2 could promote ROS production through ryanodine receptors and thus trigger $\mathrm{Ca} 2+$ sparks [4]. The involvement of NADPH and NADH in repiratory chain and cellular metabolisms makes ROS produce in all kinds of cells. Toll-like receptors (TLR) TLR1, TLR2 and TLR4 can enhance ROS production by recruiting mitochondria to macrophage phagosomes and translocating tumour necrosis factor receptor-associated factor 6 (TRAF6) to mitochondria to engage in evolutionarily conserved signalling intermediate 
in Toll pathways (ECSIT) [5]. Although ROS are mostly produced in mitochondria, the detailed mechanisms of the production are still not fully understood. However, the major factors responsible for ROS production are respiratory chain complexes (Fig. 1).

\section{Complex I}

NADH-ubiquinone oxidoreductase (Complex I) is the major source of mitochondrial ROS production in varying diseases. The components responsible for ROS production of Complex I include ubisemiquinone, flavin mononucleotide, Fe-S cluster and NAD [6]. However, ROS production by complex I in healthy state is humble presenting little oxidative damage. The major production of ROS in this state comes mainly from complex II through TCA cycle. NADH gene mutation which causes deficiency in respiratory complex I could end up in the overproduction of ROS and enhance metastasis of tumour cells [7].

\section{Complex II}

Succinate dehydrogenase (SDH) or succinate-coenzyme Q reductase (SQR) is composed of SDHA, SDHB, SDHC and SDHD. SDHA and SDHB are hydrophilic proteins. SDHC and SDHD are hydrophobic proteins that bind to ubiquinone. This oxidoreductase is also known as complex II that plays an important role in TCA cycle and respiratory chain. Succinate is the intermediate of TCA cycle and also a metabolic signature of ischaemia-reperfusion. It is responsible for ROS generation when accumulated from fumarate overproduction and malate/aspartate shuttle during reperfusion. Ischaemia injury can be ameliorated by the inhibition of succinate or ROS. Complex II turns succinate into fumarate through oxidation in mitochondria with reduced ubiquinone in the membrane [8], and succinate could be re-oxidized by $\mathrm{SDH}$, thus increasing ROS generation through reverse electron transport in mitochondria. [9].

\section{Complex III}

Ubiquinol-cytochrome $c$ oxidoreductase (Complex III) is encoded by UQCRC1 (ubiquinol-cytochrome $c$ reductase core protein 1) gene and could receive reducing equivalents from Complex I and Complex II. The received reducing equivalents are proceeded with ubiquinol and produces semiquinone for further proton transfer. p66 ${ }^{\mathrm{SHC}}$ ( $\mathrm{Src}$ homologous-collagen homologue adaptor protein) generates mitochondrial ROS as apoptosis signal through oxidation of cytochrome $c$ in mitochondrial electron transfer chain. p66 mutants could lose the ability to generate ROS and induce mitochondrial apoptosis [10], but genetic mutation may also contribute to increased generation of ROS. Isp- 1 and nuo- 6 encode complex III subunit Rieske and complex I subunit NDUFB4 (NADH dehydrogenase [ubiquinone] 1 beta subcomplex subunit 4), respectively. Mutants in isp-1 and nuo-6 are all related with enhanced ROS level that leads to lengthened lifespan. ROS promotor treatments can lengthen the wild-type lifespan while having no effect on those longevity mutants. And the enhanced ROS induces apoptosis pathway

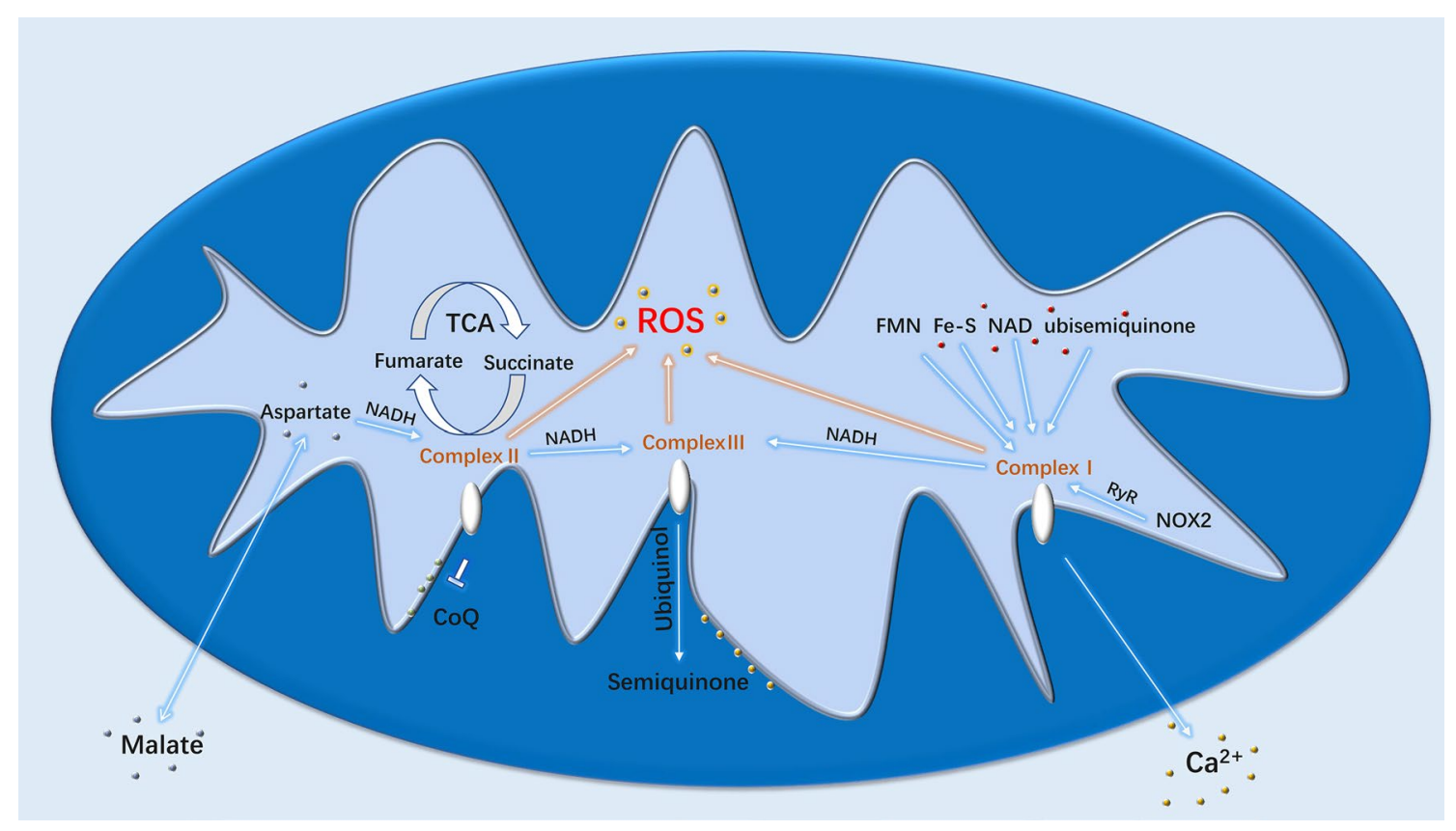

Fig. 1 Generation of ROS in mitochondria 
triggered by CED-13 that changed the gene expression to protect mitochondrial dysfunction [11]. Tumour necrosis factor alpha (TNF $\alpha)$ could regulate cell proliferation and death, and the inhibition of nuclear factor kappa-B (NF-kB) makes TNF $\alpha$ bias to cell death. TNF $\alpha$-induced ROS could support $c$-Jun $\mathrm{N}$-terminal kinase (JNK) activation during $\mathrm{NF}-\kappa \mathrm{B}$ inhibition. The sustained JNK activation enables cytochrome $\mathrm{c}$ release and leads to necrotic cell death [12].

\section{Regulation of ROS}

The homeostasis of ROS plays an important role in reducing oxidative damage and fulfil energy demand. ROS present as signalling molecules in multiple pathways and mechanisms. Thus, they are inevitably influenced by proteins and genes involved within. Apart from that, other environmental complexes and antioxidants could contribute to ROS production according to their redox potential. It is also noted that different mtDNA haplotypes may have distinct respiration capacity triggered by varying production of ROS [13] (Table 1).

\section{Downregulation of ROS}

Relatively high levels of ROS may cause oxidative damage or induce apoptosis during immunological defences or pathological conditions. The mechanisms to survive under such environment are essential for body cells or tumour cells and bacteria. Hypoxia inducible factor- 2 alpha (HIF-2 $\alpha$ ) encoded by endothelial PAS domain protein 1 (Epas1) gene could control ROS level in mitochondria through antioxidant enzymes and maintain ROS homeostasis [14]. PPAR $\gamma$ coactivator $1 \alpha$ (PGC- $1 \alpha)$ is required for antioxidative enzymes including glutathione peroxidase
1 (GPx1) and superoxide dismutase 2 (SOD2) [15]. ROS level also could be controlled through degradation of NOX2 on endoplasmic reticulum by protein negative regulator of ROS (NRROS). This reduces tissue damage and maintains its function upon immunological defence [16, 17]. However, ROS themselves could activate extracellular signal-regulated kinase (ERK) by targeting proteins Goi and $\mathrm{G} \alpha 0$ and protect cardiac cell from oxidative damage [18]. These proteins present protective effect on body cells and redox balance. It is also noted that the opened potassium channels may reduce ROS level [19].

ROS tolerance may be partly involved in the mechanisms behind the tumour cells avoiding immunological defence. Cancer cells could produce enough NADPH to support vigorous proliferation while maintaining ROS homeostasis through GSH (glutathione). Enhanced ROS in lung cancer cells could inhibit glycolytic enzyme pyruvate kinase M2 (PKM2). This also allows them to survive under acute oxidative stress and still supports their proliferation [20]. Nuclear factor erythroid-2-related factor 2 (Nrf2) transcription is increased in tumour cells to suppress ROS generation by Nrf2-Keap1 (kelch-like ECHassociated protein 1) interaction. Oncogenic alleles of K-Ras, B-Raf and Myc could increase Nrf2 antioxidant activity and reduce ROS level [21]. Researches also indicate that gene Ucp2 (uncoupling protein 2) could limit ROS production and inflammation in macrophage [22]. Apart from that, antioxidants also include organics like Vitamin E, Vitamin C and complexes like FHC (ferritin heavy chain). They reduce apoptosis induced by TNF $\alpha$ and JNK activity through suppression of ROS accumulation and iron sequestration as a downstream product of NF- $\mathrm{KB}$ pathway $[23,24]$.
Table 1 Agents involved in ROS metabolism

\begin{tabular}{lll}
\hline Regulator type & Agents & Effects \\
\hline ROS inhibitors & ERK & Reduce oxidative damage on cardiac cells \\
& NRROS & Reduce tissue damage \\
HIF-2 $\alpha$ & ROS homeostasis \\
PGC-1 $\alpha$ & Active antioxidative enzymes \\
Nrf2 & Limit ROS production in tumour \\
PKM2 & Reduce oxidative damage on lung cancer cells \\
Ucp2 & Limit inflammation ROS production in macrophage \\
Vitamin C/E, FHC & Suppress ROS accumulation \\
& TLR1, 2, 4 & Increase ROS generation in macrophage \\
NOX2 & Increase mitochondrial ROS production \\
p66 & Increase mitochondrial ROS as apoptosis signal \\
& TNF & Enhance macrophage killing and necroptosis \\
MMP-3 & DNA damage and genomic instability \\
EST-1 & Increase ROS generation \\
& UPBEAT1 & Change cells from proliferation into differentiation \\
\hline
\end{tabular}




\section{Upregulation of ROS}

ROS are important particles involved in immunological defence. Overexpressed TNF induces ROS in mitochondria through RIP1-RIP3-dependent (receptor-interacting protein kinase) pathways. The increased ROS leads to both enhanced macrophages killing and necroptosis. This necroptosis relies on mitochondrial cyclophilin D and ceramide [25]. TLR1/2/4 could enhance ROS by recruiting mitochondria to macrophage phagosomes and translocating TRAF6 to mitochondria to engage ECSIT. This further increases the bacterial killing [5]. ROS induces oxidative damage and apoptosis which may contribute to the control of lifespan. p $66^{\text {SHC }}$ generates mitochondrial ROS as apoptosis signal through oxidation of cytochrome $\mathrm{c}$ in mitochondrial electron transfer chain [10].

Other factors such as matrix metalloproteinase-3 (MMP-3 ) could increase cellular ROS and stimulate transcription factor Snail and epithelial-mesenchymal transition (EMT). This process causes DNA oxidative damage and genomic instability in breast cancer and turns normal cells into cancer cells [26]. Heart cell stretch could activate NOX2 to produce ROS through ryanodine receptors and trigger $\mathrm{Ca} 2+$ sparks [4]. The deficiency of NOX2 inhibitor NRROS could lead to elevated oxidative damage. [17] erythroblastosis virus transcription factor-1 (ETS-1) requires ROS to regulate $\mathrm{p} 47$ phox expression. However, this also could contribute to NADPH oxidase and ROS generation and become an ETS-ROS positive feedback [27]. The ROS-induced ROS-release circle could lead to elevated ROS generation as well [28]. Transcription factor UPBEAT1 could regulate the balance between cellular proliferation and differentiation through ROS. Vigorous changes in metabolism may occur during the shift from cell elongation to differentiation to fulfil metabolic demands. UPBEAT1 enhances ROS level through the repression of peroxidases which could change the pattern of cell from proliferation into differentiation. [29].

\section{ROS and diseases}

Researchers have been trying to elucidate the mechanisms and the role that ROS plays in diseases since they were identified. ROS influences diseases basically with its function as signalling molecules and oxidants that influence cell survival and oxidative damage. ROS could also drive immunity through immunological defence and maintain metabolic balance or heat dissolving. The multiple functions of ROS in biosystem may influence each pathema from different aspects (Table 2).

\section{Cancer}

Abnormal cell proliferation and metastasis are common features of cancer. Vigorous proliferation demands substantial NADPH to produce energy. This process also abundantly increases ROS. High levels of ROS could induce apoptosis of tumour cells. However, they also protect cells from oxidative damage by suppressing glycolytic enzyme PKM2 through GSH in cancer [20]. Tumour cells exhibit enhanced Nrf2 transcription. Nrf2 present as antioxidants that control ROS level in cancer. The inhibition of Nrf2 could impair tumourigenesis with increased ROS level [21]. Oncogenic alleles K-Ras, B-Raf and Myc could contribute to Nrf2-Keap1 interaction. ROS also regulate tumour suppressor protein p53 and mediate apoptosis in cancer [30]. Stem cells tend to contain lower ROS than regularly differentiated cells. Cancer stem cells also maintain low levels of ROS to avoid apoptosis induced by ROS. It also makes them suffer less DNA damage from radiation with enhanced ROS scavenging systems [31]. Cancer cells resistant to BRAF and MEK inhibitors develop vulnerability to high levels of ROS [32]. Thus, the strategy to enhance ROS level may seem to present as an important way for cancer chemotherapy.

However, researchers also indicated that tumour cells with high metastasis contain NADH gene mutation. The mutation causes deficiency in respiratory complex I and ended up in overproduction of ROS, and the metastatic activity could be suppressed with ROS scavenger [7]. Increased ROS generation could trigger enhanced epidermal growth factor receptor (EGFR) signalling and promote tumour progression [33]. Snail and EMT stimulated by MMP-3 could increase ROS generation. The elevated ROS level could turn normal cells into cancer cells with DNA damage and genomic variation. [26]. ROS could also mediate the tumour microenvironment through epithelial-mesenchymal transition that contributes to radioresistance and therapeutic failure [34]. Although suppressing ROS signalling to inhibit tumour growth with ROS scavenger is not ideal, the process of inhibition impairs ROS-mediated oxidative damage and apoptosis [35]. The uninhibited ROS generation and uncontrolled ROS level could also promote cancer cell metastasis and the process of canceration.

These controversial results bring about hindered exploration of ROS-mediated treatments against cancer. Rather than focusing on symptoms, the fundamental role of ROS and its comprehensive distribution among biosystem may explain these competing results from a broader perspective. ROS are highly related with energy production rather than just byproducts. Cancer development and tumour metastasis demand larger amounts of energy than normal cells. This energy-acquiring process also produces high levels of ROS. The enhancement of ROS may also increase energy production to facilitate tumourigenesis. Rather than a regulator of 
Table 2 The role of ROS in various diseases

\begin{tabular}{|c|c|c|}
\hline & Positive & Negative \\
\hline Cancer & $\begin{array}{l}\text { Impair tumourigenesis } \\
\text { Apoptosis }\end{array}$ & $\begin{array}{l}\text { High metastasis } \\
\text { Canceration } \\
\text { Radioresistance } \\
\text { Carcinogenesis }\end{array}$ \\
\hline Inflammatory diseases & $\begin{array}{l}\text { Prevent experimental autoimmune } \\
\text { encephalomyelitis } \\
\text { Supports immune system } \\
\text { Macrophage killing }\end{array}$ & $\begin{array}{l}\text { Inflammatory bowel diseases } \\
\text { Parasite caused organic damage } \\
\text { Periodontitis } \\
\text { Tendinopathy } \\
\text { Bronchitis } \\
\text { Emphysema } \\
\text { Rheumatoid arthritis }\end{array}$ \\
\hline Neurologic diseases & $\begin{array}{l}\text { Synaptic plasticity } \\
\text { Neuronal development }\end{array}$ & $\begin{array}{l}\text { Movement disorder } \\
\text { Neuron apoptosis } \\
\text { Neurotoxicity } \\
\text { Retardation }\end{array}$ \\
\hline Vascular diseases & $\begin{array}{l}\text { Relaxation of cerebral arteries } \\
\text { Blood flow homeostasis } \\
\text { Wound repair }\end{array}$ & $\begin{array}{l}\text { Hypertension } \\
\text { Vascular injury } \\
\text { Ischaemia-reperfusion damage } \\
\text { Retinal dysfunction } \\
\text { Pneumoconiosis } \\
\text { Atherosclerosis } \\
\text { Acute respiratory distress syndrome }\end{array}$ \\
\hline Organ failure & $\begin{array}{l}\text { Respiratory plasticity } \\
\text { Sensory plasticity }\end{array}$ & $\begin{array}{l}\text { Liver failure } \\
\text { Renal failure } \\
\text { Heart failure }\end{array}$ \\
\hline Diabetes & & Insulin resistance \\
\hline Ageing & $\begin{array}{l}\text { Muscle cell development } \\
\text { Muscle remodelling }\end{array}$ & $\begin{array}{l}\text { Sarcopenia } \\
\text { Muscular dystrophy } \\
\text { DNA damage }\end{array}$ \\
\hline Infertility & & $\begin{array}{l}\text { Damage spermatogenesis } \\
\text { Ovarian toxicity }\end{array}$ \\
\hline
\end{tabular}

the cancer pathology, ROS are more likely the representative of energy consumption. It is easy to induce cancer cells death in vitro with oxidative damage. However, the failure to apply oxidative damage to cancer cells clinically seems to be the result of ROS homeostasis system in vivo.

\section{Inflammatory diseases and infection}

Being part of the mechanisms involved in innate immunity, inflammation eliminates pathogenic factors while causing tissue damage. ROS play a similar role in immunity by enhancing immunological defence and causing oxidative damage. NLR family, pyrin domain-containing 3 (NLRP3) inflammasome could enhance inflammation by activating caspase 1 and promoting secretion of IL-1 $\beta$ and IL-18. ROS are crucial for NLRP3 activation [36]. Drosophila multipotent haematopoietic progenitors present relatively high levels of ROS in in vivo physiological conditions and become low during differentiation. The enhanced ROS could promote the differentiation through JNK and the forkhead box O (FoxO) pathway, but ROS inhibition disabled its differentiation [37]. Although the differentiation prefers low levels of ROS, they are still essential for the process. Different T-cell subsets also have distinct sensitivity to ROS level that may influence their development and function. TH17 cells are involved in autoimmune diseases and inflammatory diseases. Experimental autoimmune encephalomyelitis (EAE) is a TH17-mediated autoimmune disease. Regulating TH17 cell differentiation by interfering ROS level through glutathione metabolism could prevent EAE development [38]. Influencing chromatin structure with GLS inhibition also enhances ROS level and prevents TH17 differentiation [39]. Discovery of brand new T-cell subsets also endows deeper understanding on immune system and provides aspects for the exploration of T-cellregulated autoimmune diseases [40].

ROS could support immune system, but they become cytotoxic while overload [2]. ROS play a role in both activation-induced T-cell death and activated T-cell autonomous death [41]. Oxidative damage leads to cellular damage on DNA, protein and lipids. The damage-induced apoptosis plays an important role in inflammatory bowel diseases [42]. ROS also stimulate parasite growth and cause tissue damage to host's organs [43]. The expression of NADPH oxidase is elevated in phagocytic leukocytes upon stimuli. 
[44] The ROS-mediated autophagy could promote periodontitis and tendinopathy as well [45]. Apart from oxidative damage, ROS also serve as signalling molecules and play an important role in homeostasis, metabolism, growth and differentiation [3]. Ucp2 could limit ROS production and inflammation in macrophage and reduce parasitic cysts [22]. However, Ucp1 relies on ROS level required for heat dissipation through thermogenic respiration in brown adipose tissues. The depletion of ROS inhibits Ucp1 and heat generation [46]. Cigarette smoking induces oxidative stress in bronchitis and emphysema. Inflammation also occurs in these chronic obstructive pulmonary diseases [47].

The role of ROS in bacterial killing appears to be inconsistent among different studies. Some research state that increased ROS level in bacteria can enhance the killing ability of antibiotics and oxidants [48]. Enhanced ROS by excess TNF through RIP1-RIP3-dependent pathways in mitochondria lead to both enhanced macrophages killing and necroptosis that relies on mitochondrial cyclophilin D and ceramide [25]. TNF- $\alpha$ is indicated to contribute to ROS production in rheumatoid arthritis [49]. However, other studies indicate that ROS response during bacterial antibiotic killing is dispensable [50]. ROS scavenger and hydroxyl radical inhibitor could suppress antibiotic bacterial killing. Antibiotic bacterial killing does not strictly depend on ROS [51]. It is also noted that the level of ROS does not influence antibiotics' activity on killing bacteria at all [52]. Antibiotic killing of Escherichia coli does not rely on ROS [53]. The enhanced bacterial killing with increased ROS level may due to increased metabolism and energy supply that support oxidation and immunity system. However, it applies little effect when they reaches saturation. But moderated metabolism with lower levels of ROS surely decreases the ability of bacterial killing.

\section{Neurodegeneration}

Neurons are important cells that control sensory organs and muscle system. The injury of these cells may lead to neuropathy and movement disorder. The relatively low antioxidant activity makes them vulnerable to oxidative damage. The defects in mitochondria may enhance ROS generation and thus promote JNK and sterol-regulatory element binding proteins (SREBP) activation in neurons that results in neurodegeneration through the accumulation of lipid droplets [54]. The adipogenesis could also be influenced by ROS via signal transducers and activators of transcription 3 (STAT3) [55]. However, antioxidants could rescue the apoptosis [56]. FHC could suppress ROS accumulation and JNK activity through iron sequestration that inhibits TNF- $\alpha$-dependent apoptosis [24]. PGC- $1 \alpha$ could protect neural cells from oxidative damage by reducing ROS level via antioxidative enzymes GPx1 and SOD2 [15]. Methylmercury and manganese could induce neurotoxicity with enhanced ROS level $[57,58]$. And the increased level of ROS in the substantia nigra pars compacta leads to neuronal apoptosis of dopaminergic neurons in Down syndrome and Parkinson's disease. This process may ultimately lead to retardation [59]. NRROS could protect central nervous system from EAE by reducing oxidative damage through NOX2 degradation on endoplasmic reticulum [17]. Nevertheless, ROS still play an important role in neuronal development and are essential for synaptic plasticity and memory formation with its fundamental role in energy perfusion. The essence that neurons are differentiated cells that lack the potential to proliferate explained these competing results of antioxidative strategies. They maintain a relatively low demand in energy and metabolism.

\section{Cardiac diseases}

In the heart, angiotensin II, norepinephrine and TNF- $\alpha$ mediated ROS are related with cardiac hypertrophy, myocardial infarction and heart failure. Myocardial ischaemia is the most common cause of heart failure. The ischaemia-reperfusion injury leads to apoptosis of cardiomyocytes that is associated with high levels of ROS [60]. The shortage of ATP during ischaemia impairs ion pump and causes calcium accumulation. Calcium overload and increased ROS could rupture plasma membrane and lead to cell death [61]. Cardiac hypertrophy is a compensating process that enables heart to maintain sufficient function. The increased ROS during the process is responsive to energy demand caused by insufficient heart function. Thioredoxin 1 could reduce cardiac hypertrophy through heat shock protein 40 and class II histone deacetylases, the latter being a master negative regulator of cardiac hypertrophy [62]. And it is also noted that ROS increased via D-amino acid oxidase in the hearts of rats could directly lead to systolic heart failure without cardiac hypertrophy [63]. The oxidative damage-mediated apoptosis is the major cause of heart failure as well. The method to fulfil energy demand by using NOX4 to protect heart from failure with improved myocardial energetics via fatty acid oxidation is also proved to be successful [64]. To reduce oxidative damage, ubiA prenyltransferase domain-containing protein 1 presents cardiovascular protective function via antioxidant Coenzyme Q10 [65]. However, the inability to recover from cardiac damage and pathology is also critical for heart failure. Postnatal cardiomyocyte cell-cycle arrest is mediated by ROS through DNA damage response [66]. Heart cell stretch could cause arrhythmogenic $\mathrm{Ca}^{2+}$ sparks based on microtubules [7]. Although the oxidative damage caused by ROS is the major reason for heart failure, the role of ROS in energy supply is rather important that protect heart from an even sudden failure of insufficient function. 


\section{Vascular diseases}

ROS regulate vascular cell proliferation and apoptosis with their fundamental role in metabolism. Oxidative stress could lead to hypertension and promote its pathological process. However, ROS are also needed for the relaxation of cerebral arteries [67]. ETS-1 and angiotensin II-generated ROS play an important role in vascular changes and injury, and NO could regulate blood flow homeostasis in blood vessels [68]. These outcomes seem to be confusing to tell whether ROS are beneficial or harmful. The role of ROS in biosystem is rather neutral that they mainly respond to energy demand. NOX family could influence the neovascularity of tumour and physiological vascular processes [69]. Similar results also presented in ROS-mediated wound repair [70]. Ischaemia-reperfusion (IR) causes oxidative damage with increased generation of ROS in mitochondria. Succinate is the metabolic signature of ischaemia and responsible for ROS generation during reperfusion. The reperfusion injury also leads to retinal dysfunction-associated ROS production when the blood pressure is low [71]. Succinate accumulates during reperfusion from fumarate overproduction and malate/aspartate shuttle and then re-oxidized by succinate dehydrogenase. This process increases ROS generation through reverse electron transport in mitochondria. The inhibition of succinate or ROS could ameliorate IR injury [9]. Pre-conditioning protocols could reduce ischaemia-reperfusion injury by regulating ROS level [72].

Atherosclerosis could be regulated by ROS interacting with transcription factors related with lipid peroxidation and macrophage [73]. ROS induces DNA damage and lipid peroxidation in pneumoconiosis and carcinogenesis as well [74]. Increased ROS promote thrombus formation in artery and influence other cardiovascular diseases as well [75, 76]. The pulmonary vascular lesions and inflammation are broadly recognized pathological changes in acute respiratory distress syndrome (ARDS) caused by oxidative damage [77]. Taken together, researchers revealed the position of ROS in metabolism and energy supply. ROS are needed for basic energy demand and vigorous metabolism rather than simply affecting cellular signalling and organism damages.

\section{Organ failure}

The continuous oxidative damage applied on cell and tissue may lead to severe organic injuries and eventually cause organ failure. The ROS level leading to organ failures far exceeds the extent to maintain basic metabolism and thus the balance between energy supply and oxidative damage is tilted. Increasing ROS grants little beneficial effect in this situation. Inhibition of ROS could reduce TNF- $\alpha$-mediated fulminant liver failure. TNF $\alpha$ regulates cell proliferation and death and the inhibition of NF- $\mathrm{KB}$ makes TNF $\alpha$ bias to cell death. TNF $\alpha$-induced ROS supports JNK activation during NF-kB inhibition. Sustained JNK activation enables cytochrome c release and leads to necrotic cell death [12]. FHC is a downstream product of NF- $\kappa \mathrm{B}$. They could reduce apoptosis induced by TNF $\alpha$ through suppression of ROS accumulation and JNK activity. The suppression of ROS is achieved by iron sequestration [24]. ROS are produced by glomerular cells as autacoids [78]. ROS-mediated glomerular basement membrane degradation and altered cell function may contribute to ischaemic renal failure as well [79]. And the inhibition of ROS could decrease $\mathrm{CaOx}$ stone in kidney [80]. Hypoxia-induced requirement of energy supply and metabolism could lead to increased ROS response through $\mathrm{Ca}^{2+}$ influx pathway. This mechanism results in physiological, biochemical and molecular changes. The hypoxia-induced ROS production is important for respiratory plasticity and sensory plasticity. ROS-mediated apoptosis and cellular dysfunction are associated with heart failure [60]. The arrhythmias caused by elevated ROS and altered mitochondrial function may lead to sudden cardiac death [81].

\section{Other diseases}

The comprehensive distribution of ROS intrigues researchers to explore the relationship between their subject and ROS. The reduced ROS level could lower insulin resistance and improve insulin sensitivity in diabetes II [82], and the glucose-stimulated insulin relies on ROS signalling [83]. However, the cellular death owing to ROS-mediated oxidative damage also brings about diabetic complications [84]. MMP activity and transcription factor- $\beta 1$ (TGF- $\beta 1$ )-induced excessive deposition of extracellular matrix mediated by ROS could lead to renal fibrosis [85].

The process of ageing caused by oxidative damage and muscle dysfunction could lead to sarcopenia. However, ROS are also essential for muscle cell development as signalling molecules [86]. Generation of ROS in skeletal muscle is enhanced during contractile activity [87]. ROS are increased in the early stage of muscular dystrophy development [88]. The elevated ROS may reduce muscle mass and bring about frailty [89]. However, ROS also plays an important role in muscle remodelling as signalling molecules [90]. Overproduced ROS released through mitochondrial permeability transition pore will damage DNA and accelerate ageing by reducing cellular NAD [91]. Apart from suppressing tumour, p53 also plays a role in premature ageing by causing reactive damage to DNA [92]. Mushroom-contained antioxidants may protect against oxidative damage and ageing [93].

ROS overproduction may contribute to reproductivity issue and infertility through oxidative damage and disturbed hormone balance. The excessive ROS may damage spermatogenesis, sperm lipid/protein layer and DNA structure. The 
ROS scavenging system to reduce ovarian toxicity is important for follicular development [94]. The role of ROS seems to be similar in different diseases that they are essential for cellular metabolism and become pathogenic while overload.

\section{Conclusions and perspectives}

Researches of ROS have been carried out since last century, the cognition of which varies along elapse of time. ROS promote macrophage bacterial killing through oxidative damage and apoptosis. They also engage in multiple cellular pathways as signalling molecules. However, they also have negative effects like inflammation and cytotoxicity. ROS can function as intermediates in varying pathways, but they are also widely regarded as etiologic factors for diseases including cancer, inflammation and organ injuries. Evidence suggests that the scavenging ROS in pathological condition may reduce cell damage and control the pathological process. However, other researches also indicate the positive side of enhancing ROS in diseases. Thus, the mechanisms of how ROS influences diseases remain obscure. Europeans have dedicated to the study of ROS and made a comprehensive exploration [95]. Yet, it remains controversial in results of ROS-targeted strategies applied to clinical research. With the advancement in technique, ROS can be measured in living cells of its transient generation with Y0.6Eu0.4VO4 nanoparticles by illuminating under oxidative conditions [96]. Specific chemical probes and low-temperature electron paramagnetic resonance (EPR) technique could monitor ROS level of tumour cells in vitro and in vivo [97]. Other environmental factors like $\mathrm{pH}$ and ion concentration are also suggested in ROS regulation and generation [98]. Also magnetic fields could influence cellular ROS level according to its intensity, frequency and exposure time [99].

The fundamental understandings of ROS remain basically the same in the past 20 years. ROS are generally regarded as signalling molecules and harmful particles. Researchers always focus on ROS levels and their results and analyses them from a single perspective. They should be illuminated from different perspectives and with extensive sight. Based upon the characteristics of ROS discovered by previous researches, I provide a hypothesis here that may explain the competing results so far. ROS thrives in conditions that abundant energy is in demand for vigorous metabolism, either in cancer cells' proliferation and inflammatory necrosis, or immunological defence required immune system functioning. Thus, ROS do not just act as signalling molecules. They may present as basic energy particles like other acknowledged basic nutrient particles including proteins and carbohydrates. And they provide a much more fundamental impact on cellular metabolism. It is more likely that ROS respond to elevated metabolism to fulfil energy demand, rather than directly bending itself to oxidative stress, which interprets why different researches demonstrate controversial outcome in regulating ROS. The treatment of both inhibition and enhancement of ROS in cancer in vitro may due to exhausted energy supply for metabolism and overload of energy supply-induced oxidative damage, rather than just the regulation of a byproduct. Of course, it is easier to suppress ROS generation with antioxidants or genetic depletion in experimental animal models. But the inability of clinically gene modulation in vivo and the multiple functions of ROS in metabolism may lead to limited potrential of direct ROS modulation in diseases with ROS and metabolic imbalance. The fundamental role of ROS grants them with the potential in metabolic regulation. From another aspect, the essence that ROS are common particles with comprehensive distribution endows them with more fundamental mechanisms to be explored.

\section{Compliance with ethical standards}

Conflict of interest The authors declare that they have no conflict of interest.

\section{References}

1. Bedard K, Krause KH (2007) The NOX family of ROS-generating NADPH oxidases: physiology and pathophysiology. Physiol Rev 87(1):245-313. https://doi.org/10.1152/physrev.00044.2005

2. Nathan C, Cunningham-Bussel A (2013) Beyond oxidative stress: an immunologist's guide to reactive oxygen species. Nat Rev Immunol 13(5):349-361. https://doi.org/10.1038/nri3423

3. Shadel GS, Horvath TL (2015) Mitochondrial ROS signaling in organismal homeostasis. Cell 163(3):560-569. https://doi. org/10.1016/j.cell.2015.10.001

4. Prosser BL, Ward CW, Lederer WJ (2011) X-ROS signaling: rapid mechano-chemo transduction in heart. Science 333(6048):1440 1445. https://doi.org/10.1126/science. 1202768

5. West AP, Brodsky IE, Rahner C, Woo DK, Erdjument-Bromage H, Tempst P, Walsh MC, Choi Y, Shadel GS, Ghosh S (2011) TLR signalling augments macrophage bactericidal activity through mitochondrial ROS. Nature 472(7344):476-480. https://doi. org/10.1038/nature09973

6. Zorov DB, Juhaszova M, Sollott SJ (2014) Mitochondrial reactive oxygen species (ROS) and ROS-induced ROS release. Physiol Rev 94(3):909-950. https://doi.org/10.1152/physrev.00026.2013

7. Ishikawa K, Takenaga K, Akimoto M, Koshikawa N, Yamaguchi A, Imanishi H, Nakada K, Honma Y, Hayashi J et al (2008) ROSgenerating mitochondrial DNA mutations can regulate tumor cell metastasis. Science 320(5876):661-664. https://doi.org/10.1126/ science. 1156906

8. Yankovskaya V, Horsefield R, Tornroth S, Luna-Chavez C, Miyoshi H, Leger C, Byrne B, Cecchini G, Iwata S (2003) Architecture of succinate dehydrogenase and reactive oxygen species generation. Science 299(5607):700-704. https://doi.org/10.1126/ science. 1079605

9. Chouchani ET, Pell VR, Gaude E, Aksentijevic D, Sundier SY, Robb EL, Logan A, Nadtochiy SM, Ord ENJ, Smith AC, Eyassu F, Shirley R, Hu CH, Dare AJ, James AM, Rogatti S, Hartley RC, 
Eaton S, Costa ASH, Brookes PS, Davidson SM, Duchen MR, Saeb-Parsy K, Shattock MJ, Robinson AJ, Work LM, Frezza C, Krieg T, Murphy MP (2014) Ischaemic accumulation of succinate controls reperfusion injury through mitochondrial ROS. Nature 515(7527):431-435. https://doi.org/10.1038/nature13909

10. Giorgio M, Migliaccio E, Orsini F, Paolucci D, Moroni M, Contursi C, Pelliccia G, Luzi L, Minucci S, Marcaccio M, Pinton P, Rizzuto R, Bernardi P, Paolucci F, Pelicci PG (2005) Electron transfer between cytochrome $\mathrm{c}$ and $\mathrm{p} 66 \mathrm{Shc}$ generates reactive oxygen species that trigger mitochondrial apoptosis. Cell 122(2):221233. https://doi.org/10.1016/j.cell.2005.05.011

11. Yee C, Yang W, Hekimi S (2014) The intrinsic apoptosis pathway mediates the pro-longevity response to mitochondrial ROS in C. elegans. Cell 157(4):897-909. https://doi.org/10.1016/j. cell.2014.02.055

12. Kamata H, Honda S, Maeda S, Chang L, Hirata H, Karin M (2005) Reactive oxygen species promote TNFalpha-induced death and sustained JNK activation by inhibiting MAP kinase phosphatases. Cell 120(5):649-661. https://doi.org/10.1016/j.cell.2004.12.041

13. Moreno-Loshuertos R, Acin-Perez R, Fernandez-Silva P, Movilla N, Perez-Martos A, Rodriguez de Cordoba S, Gallardo ME, Enriquez JA (2006) Differences in reactive oxygen species production explain the phenotypes associated with common mouse mitochondrial DNA variants. Nat Genet 38(11):1261-1268. https ://doi.org/10.1038/ng1897

14. Scortegagna M, Ding K, Oktay Y, Gaur A, Thurmond F, Yan LJ, Marck BT, Matsumoto AM, Shelton JM, Richardson JA, Bennett MJ, Garcia JA (2003) Multiple organ pathology, metabolic abnormalities and impaired homeostasis of reactive oxygen species in Epas1 $^{-/-}$mice. Nat Genet 35(4):331-340. https://doi.org/10.1038/ ng1266

15. St-Pierre J, Drori S, Uldry M, Silvaggi JM, Rhee J, Jager S, Handschin C, Zheng K, Lin J, Yang W, Simon DK, Bachoo R, Spiegelman BM (2006) Suppression of reactive oxygen species and neurodegeneration by the PGC-1 transcriptional coactivators. Cell 127(2):397-408. https://doi.org/10.1016/j.cell.2006.09.024

16. Leavy O (2014) Inflammation: regulating ROS. Nat Rev Immunol 14(6):357. https://doi.org/10.1038/nri3685

17. Noubade R, Wong K, Ota N, Rutz S, Eidenschenk C, Valdez PA, Ding J, Peng I, Sebrell A, Caplazi P, DeVoss J, Soriano RH, Sai T, Lu R, Modrusan Z, Hackney J, Ouyang W (2014) NRROS negatively regulates reactive oxygen species during immunological defence and autoimmunity. Nature 509(7499):235-239. https ://doi.org/10.1038/nature13152

18. Nishida M, Maruyama Y, Tanaka R, Kontani K, Nagao T, Kuroseet $\mathrm{H}$ et al (2000) $\mathrm{G} \alpha \mathrm{i}$ and $\mathrm{G} \alpha 0$ are target proteins of reactive oxygen species. Nature 408(6811):492-495. https://doi. org/10.1038/35044120

19. Malinska D, Mirandola SR, Kunz WS (2010) Mitochondrial potassium channels and reactive oxygen species. FEBS Lett 584(10):2043-2048. https://doi.org/10.1016/j.febslet.2010.01.013

20. Anastasiou D, Poulogiannis G, Asara JM, Boxer MB, Jiang JK, Shen M, Bellinger G, Sasaki AT, Locasale JW, Auld DS, Thomas CJ, Vander Heiden MG, Cantley LC (2011) Inhibition of pyruvate kinase $\mathrm{M} 2$ by reactive oxygen species contributes to cellular antioxidant responses. Science 334(6060):1278-1283. https://doi. org/10.1126/science.1211485

21. DeNicola GM, Karreth FA, Humpton TJ, Gopinathan A, Wei C, Frese K, Mangal D, Yu KH, Yeo CJ, Calhoun ES, Scrimieri F, Winter JM, Hruban RH, Iacobuzio-Donahue C, Kern SE, Blair IA, Tuveson DA (2011) Oncogene-induced Nrf2 transcription promotes ROS detoxification and tumorigenesis. Nature 475(7354):106-109. https://doi.org/10.1038/nature10189

22. Arsenijevic D, Onuma H, Pecqueur C, Raimbault S, Manning B, Miroux B, Couplan E, Alves-Guerra M, Goubernet M, Surwit R et al (2000) Disruption of the uncoupling protein-2 gene in mice reveals a role in immunity and reactive oxygen species production. Nat Genet 26(4):435-439. https://doi.org/10.1038/82565

23. Yu BP (1994) Cellular defenses against damage from reactive oxygen species. Physiol Rev 74(1):139-162. https://doi.org/10.1152/ physrev.1994.74.1.139

24. Pham CG, Bubici C, Zazzeroni F, Papa S, Jones J, Alvarez K, Jayawardena S, De Smaele E, Cong R, Beaumont C, Torti FM, Torti SV, Franzoso G (2004) Ferritin heavy chain upregulation by NF-kappaB inhibits TNFalpha-induced apoptosis by suppressing reactive oxygen species. Cell 119(4):529-542. https:// doi.org/10.1016/j.cell.2004.10.017

25. Roca FJ, Ramakrishnan L (2013) TNF dually mediates resistance and susceptibility to mycobacteria via mitochondrial reactive oxygen species. Cell 153(3):521-534. https://doi.org/10.1016/j. cell.2013.03.022

26. Radisky DC, Levy DD, Littlepage LE, Liu H, Nelson CM, Fata JE, Leake D, Godden EL, Albertson DG, Nieto MA, Werb Z, Bissell MJ (2005) Rac1b and reactive oxygen species mediate MMP3-induced EMT and genomic instability. Nature 436(7047):123127. https://doi.org/10.1038/nature03688

27. Shiu YT, Jaimes EA (2018) Transcription factor ETS-1 and reactive oxygen species: role in vascular and renal injury. Antioxidants 7(7):84. https://doi.org/10.3390/antiox7070084

28. Zorov DB, Juhaszova M, Sollott SJ (2006) Mitochondrial ROSinduced ROS release: an update and review. Biochim Biophys Acta 1757(5-6):509-517. https://doi.org/10.1016/j.bbabi o.2006.04.029

29. Tsukagoshi H, Busch W, Benfey PN (2010) Transcriptional regulation of ROS controls transition from proliferation to differentiation in the root. Cell 143(4):606-616. https://doi.org/10.1016/j. cell.2010.10.020

30. Liu B, Chen Y, St Clair DK (2008) ROS and p53: a versatile partnership. Free Radic Biol Med 44(8):1529-1535. https://doi. org/10.1016/j.freeradbiomed.2008.01.011

31. Diehn M, Cho RW, Lobo NA, Kalisky T, Dorie MJ, Kulp AN, Qian D, Lam JS, Ailles LE, Wong M, Joshua B, Kaplan MJ, Wapnir I, Dirbas FM, Somlo G, Garberoglio C, Paz B, Shen J, Lau SK, Quake SR, Brown JM, Weissman IL, Clarke MF (2009) Association of reactive oxygen species levels and radioresistance in cancer stem cells. Nature 458(7239):780-783. https://doi.org/10.1038/ nature 07733

32. Seton-Rogers S (2018) Lethally high ROS levels thwart resistance. Nat Rev Cancer 18(7):403. https://doi.org/10.1038/s4156 8-018-0031-6

33. Weng MS, Chang JH, Hung WY, Yang YC, Chien MH (2018) The interplay of reactive oxygen species and the epidermal growth factor receptor in tumor progression and drug resistance. J Exp Clin Cancer Res 37(1):61. https://doi.org/10.1186/s13046-018-0728-0

34. Gu H, Huang T, Shen Y, Liu Y, Zhou F, Jin Y, Sattar H, Wei Y (2018) Reactive oxygen species-mediated tumor microenvironment transformation: the mechanism of radioresistant gastric cancer. Oxid Med Cell Longev 2018:5801209. https://doi. org/10.1155/2018/5801209

35. Trachootham D, Alexandre J, Huang P (2009) Targeting cancer cells by ROS-mediated mechanisms: a radical therapeutic approach? Nat Rev Drug Discov 8(7):579-591. https://doi. org/10.1038/nrd2803

36. Tschopp J, Schroder K (2010) NLRP3 inflammasome activation: the convergence of multiple signalling pathways on ROS production? Nat Rev Immunol 10(3):210-215. https://doi.org/10.1038/ nri2725

37. Owusu-Ansah E, Banerjee U (2009) Reactive oxygen species prime Drosophila haematopoietic progenitors for differentiation. Nature 461(7263):537-541. https://doi.org/10.1038/nature08313

38. Lang G, Gnanaprakasam JR, Wang T, Wu R, Chen X, Liu L, Shen Y, Yang M, Yang J, Chen Y, Vasiliou V, Cassel TA, Green 
DR, Liu Y, Fan TW, Wang R (2018) Glutathione de novo synthesis but not recycling process coordinates with glutamine catabolism to control redox homeostasis and directs murine T cell differentiation. Elife 7:e36158. https://doi.org/10.7554/ eLife.36158

39. Johnson MO, Wolf MM, Madden MZ, Andrejeva G, Sugiura A, Contreras DC, Maseda D, Liberti MV, Paz K, Kishton RJ, Johnson ME, de Cubas AA, Wu P, Li G, Zhang Y, Newcomb DC, Wells AD, Restifo NP, Rathmell WK, Locasale JW, Davila ML, Blazar BR, Rathmell JC (2018) Distinct regulation of Th17 and Th1 cell differentiation by glutaminase-dependent metabolism. Cell 175(7):1780-1795. https://doi.org/10.1016/j. cell.2018.10.001 (e1719)

40. Caielli S, Veiga DT, Balasubramanian P, Athale S, Domic B, Murat E, Banchereau R, Xu Z, Chandra M, Chung CH, Walters L, Baisch J, Wright T, Punaro M, Nassi L, Stewart K, Fuller J, Ucar D, Ueno H, Zhou J, Banchereau J, Pascual V (2019) A $\mathrm{CD} 4(+) \mathrm{T}$ cell population expanded in lupus blood provides B cell help through interleukin-10 and succinate. Nat Med 25(1):75-81. https://doi.org/10.1038/s41591-018-0254-9

41. Hildeman D, Mitchell T, Kappler J, Marrack P (2003) T cell apoptosis and reactive oxygen species. J Clin Investig 111(5):575-581. https://doi.org/10.1172/JCI18007

42. Patlevic P, Vaskova J, Svorc P Jr, Vasko L, Svorc P (2016) Reactive oxygen species and antioxidant defense in human gastrointestinal diseases. Integr Med Res 5(4):250-258. https://doi. org/10.1016/j.imr.2016.07.004

43. Gubbels M-J, Paiva CN, Medei E, Bozza MT (2018) ROS and Trypanosoma cruzi: fuel to infection, poison to the heart. PLOS Pathog 14(4):e1006928. https://doi.org/10.1371/journ al.ppat. 1006928

44. Robinson JM (2008) Reactive oxygen species in phagocytic leukocytes. Histochem Cell Biol 130(2):281-297. https://doi. org/10.1007/s00418-008-0461-4

45. Tunstall Pedoe DS (2004) Sudden death risk in older athletes: increasing the denominator. Br J Sports Med 38(6):671-672. https://doi.org/10.1136/bjsm.2003.006064

46. Chouchani ET, Kazak L, Jedrychowski MP, Lu GZ, Erickson BK, Szpyt J, Pierce KA, Laznik-Bogoslavski D, Vetrivelan R, Clish CB, Robinson AJ, Gygi SP, Spiegelman BM (2016) Mitochondrial ROS regulate thermogenic energy expenditure and sulfenylation of UCP1. Nature 532(7597):112-116. https://doi. org/10.1038/nature17399

47. Boukhenouna S, Wilson MA, Bahmed K, Kosmider B (2018) Reactive oxygen species in chronic obstructive pulmonary disease. Oxid Med Cell Longev 2018:5730395. https://doi. org/10.1155/2018/5730395

48. Brynildsen MP, Winkler JA, Spina CS, MacDonald IC, Collins JJ (2013) Potentiating antibacterial activity by predictably enhancing endogenous microbial ROS production. Nat Biotechnol 31(2):160-165. https://doi.org/10.1038/nbt.2458

49. Mirshafiey A, Mohsenzadegan M (2008) The role of reactive oxygen species in immunopathogenesis of rheumatoid arthritis. Iran J Allergy Asthma Immunol 7(4):195-202

50. Ezraty B, Vergnes A, Banzhaf M, Duverger Y, Huguenot A, Brochado AR, Su SY, Espinosa L, Loiseau L, Py B, Typas A, Barras F (2013) Fe-S cluster biosynthesis controls uptake of aminoglycosides in a ROS-less death pathway. Science 340(6140):1583-1587. https://doi.org/10.1126/science.1238328

51. Fang FC (2013) Antibiotic and ROS linkage questioned. Nat Biotechnol 31(5):415-416. https://doi.org/10.1038/nbt.2574

52. Keren I, Wu Y, Inocencio J, Mulcahy L, Lewiset K et al (2013) Killing by bactericidal antibiotics does not depend on reactive oygen species. Science 339(6124):1213-1216. https://doi. org/10.1126/science. 1232688
53. Liu Y, Imlay JA (2013) Cell death from antibiotics without the involvement of reactive oxygen species. Science 339(6124):1210 1213. https://doi.org/10.1126/science. 1232751

54. Liu L, Zhang K, Sandoval H, Yamamoto S, Jaiswal M, Sanz E, Li Z, Hui J, Graham BH, Quintana A, Bellen HJ (2015) Glial lipid droplets and ROS induced by mitochondrial defects promote neurodegeneration. Cell 160(1-2):177-190. https://doi.org/10.1016/j. cell.2014.12.019

55. Kramer AH, Kadye R, Houseman PS, Prinsloo E (2015) Mitochondrial STAT3 and reactive oxygen species: a fulcrum of adipogenesis? JAK-STAT 4(2):e1084084. https://doi. org/10.1080/21623996.2015.1084084

56. Busciglio J, Yankner BA (1995) Apoptosis and increased generation of reactive oxygen species in Down's syndrome neurons in vitro. Nature 378(6559):776-779. https://doi. org/10.1038/378776a0

57. Aschner M, Syverse T, Souza D, Rocha J, Farina M (2007) Involvement of glutamate and reactive oxygen species in methylmercury neurotoxicity. Braz J Med Biol Res 40(3):285-291. https ://doi.org/10.1590/s0100-879x2007000300001

58. Martinez-Finley EJ, Gavin CE, Aschner M, Gunter TE (2013) Manganese neurotoxicity and the role of reactive oxygen species. Free Radic Biol Med 62:65-75. https://doi.org/10.1016/j.freer adbiomed.2013.01.032

59. Tieu K, Ischiropoulos H, Przedborski S (2003) Nitric oxide and reactive oxygen species in Parkinson's disease. IUBMB Life 55(6):329-335. https://doi.org/10.1080/1521654032000114320

60. Sorescu D, Griendling KK (2002) Reactive oxygen species, mitochondria, and $\mathrm{NAD}(\mathrm{P}) \mathrm{H}$ oxidases in the development and progression of heart failure. Congest Heart Fail 8(3):132-140

61. Ago T, Liu T, Zhai P, Chen W, Li H, Molkentin JD, Vatner SF, Sadoshima J (2008) A redox-dependent pathway for regulating class II HDACs and cardiac hypertrophy. Cell 133(6):978-993. https://doi.org/10.1016/j.cell.2008.04.041

62. Steinhorn B, Sorrentino A, Badole S, Bogdanova Y, Belousov V, Michel T (2018) Chemogenetic generation of hydrogen peroxide in the heart induces severe cardiac dysfunction. Nat Commun 9(1):4044. https://doi.org/10.1038/s41467-018-06533-2

63. Nabeebaccus A, Hafstad A, Eykyn T, Yin X, Brewer A, Zhang M, Mayr M, Shah A (2015) Cardiac-targeted NADPH oxidase 4 in the adaptive cardiac remodelling of the murine heart. The Lancet 385:S73. https://doi.org/10.1016/s0140-6736(15)60388-9

64. Puente BN, Kimura W, Muralidhar SA, Moon J, Amatruda JF, Phelps KL, Grinsfelder D, Rothermel BA, Chen R, Garcia JA, Santos CX, Thet S, Mori E, Kinter MT, Rindler PM, Zacchigna S, Mukherjee S, Chen DJ, Mahmoud AI, Giacca M, Rabinovitch PS, Aroumougame A, Shah AM, Szweda LI, Sadek HA (2014) The oxygen-rich postnatal environment induces cardiomyocyte cellcycle arrest through DNA damage response. Cell 157(3):565-579. https://doi.org/10.1016/j.cell.2014.03.032

65. Murphy E, Steenbergen C (2008) Mechanisms underlying acute protection from cardiac ischemia-reperfusion injury. Physiol Rev 88(2):581-609. https://doi.org/10.1152/physrev.00024.2007

66. Mugoni V, Postel R, Catanzaro V, De Luca E, Turco E, Digilio G, Silengo L, Murphy Michael P, Medana C, Stainier Didier YR, Bakkers J, Santoro Massimo M (2013) Ubiad1 is an antioxidant enzyme that regulates eNOS activity by CoQ10 synthesis. Cell 152(3):504-518. https://doi.org/10.1016/j.cell.2013.01.013

67. Faraci FM (2006) Reactive oxygen species: influence on cerebral vascular tone. J Appl Physiol 100(2):739-743. https://doi. org/10.1152/japplphysiol.01044.2005

68. Tejero J, Shiva S, Gladwin MT (2019) Sources of vascular nitric oxide and reactive oxygen species and their regulation. Physiol Rev 99(1):311-379. https://doi.org/10.1152/physrev.00036.2017

69. Heerebeek L, Meischl C, Stooker W, Meijer C, Niessen H, Roos D (2002) NADPH oxidase(s): new source(s) of reactive oxygen 
species in the vascular system? J Clin Pathol 55(8):561-568. https://doi.org/10.1136/jcp.55.8.561

70. Andre-Levigne D, Modarressi A, Pepper MS, Pittet-Cuenod B (2017) Reactive oxygen species and NOX enzymes are emerging as key players in cutaneous wound repair. Int $\mathrm{J}$ Mol Sci 18(10):2149. https://doi.org/10.3390/ijms18102149

71. McMonnies C (2018) Reactive oxygen species, oxidative stress, glaucoma and hyperbaric oxygen therapy. J Optom 11(1):3-9. https://doi.org/10.1016/j.optom.2017.06.002

72. Minutoli L, Puzzolo D, Rinaldi M, Irrera N, Marini H, Arcoraci V, Bitto A, Crea G, Pisani A, Squadrito F, Trichilo V, Bruschetta D, Micali A, Altavilla D (2016) ROS-mediated NLRP3 inflammasome activation in brain, heart, kidney, and testis ischemia/ reperfusion injury. Oxid Med Cell Longev 2016:2183026. https ://doi.org/10.1155/2016/2183026

73. Halliwell B (1989) Free radicals, reactive oxygen species and human disease: a critical evaluation with special reference to atherosclerosis. Br J Exp Pathol 70(6):737-757

74. Vallyathan V, Shi X, Castranova V (1998) Reactive oxygen species: their relation to pneumoconiosis and carcinogenesis. Environ Health Perspect 106(Suppl 5):1151-1155. https://doi. org/10.1289/ehp.98106s51151

75. Moris D, Spartalis M, Spartalis E, Karachaliou GS, Karaolanis GI, Tsourouflis G, Tsilimigras DI, Tzatzaki E, Theocharis S (2017) The role of reactive oxygen species in the pathophysiology of cardiovascular diseases and the clinical significance of myocardial redox. Ann Transl Med 5(16):326. https://doi. org/10.21037/atm.2017.06.27

76. Qiao J, Arthur JF, Gardiner EE, Andrews RK, Zeng L, Xu K (2018) Regulation of platelet activation and thrombus formation by reactive oxygen species. Redox Biol 14:126-130. https://doi. org/10.1016/j.redox.2017.08.021

77. Chabot F, Mitchell J, Gutteridge J, Evanset T (1998) Reactive oxygen species in acute lung injury. Eur Respir J 11(3):745-757

78. Baud L, Fouqueray B, Philippe C, Ardaillou R (1992) Reactive oxygen species as glomerular autacoids. J Am Soc Nephrol 2(10 Suppl):S132-138

79. Baud L, Ardaillou R (1986) Reactive oxygen species: production and role in the kidney. Am J Physiol 251(5 Pt 2):F765-776. https://doi.org/10.1152/ajprenal.1986.251.5.F765

80. Khan SR (2013) Reactive oxygen species as the molecular modulators of calcium oxalate kidney stone formation: evidence from clinical and experimental investigations. J Urol 189(3):803-811. https://doi.org/10.1016/j.juro.2012.05.078

81. Jeong EM, Liu M, Sturdy M, Gao G, Varghese ST, Sovari AA, Dudley SC Jr (2012) Metabolic stress, reactive oxygen species, and arrhythmia. J Mol Cell Cardiol 52(2):454-463. https://doi. org/10.1016/j.yjmcc.2011.09.018

82. Houstis N, Rosen ED, Lander ES (2006) Reactive oxygen species have a causal role in multiple forms of insulin resistance. Nature 440(7086):944-948. https://doi.org/10.1038/nature0463 4

83. Pi J, Zhang Q, Fu J, Woods CG, Hou Y, Corkey BE, Collins S, Andersen ME (2010) ROS signaling, oxidative stress and Nrf2 in pancreatic beta-cell function. Toxicol Appl Pharmacol 244(1):7783. https://doi.org/10.1016/j.taap.2009.05.025

84. Wagener FA, Dekker D, Berden JH, Scharstuhl A, van der Vlag $J$ (2009) The role of reactive oxygen species in apoptosis of the diabetic kidney. Apoptosis 14(12):1451-1458. https://doi. org/10.1007/s10495-009-0359-1

85. Ha H (2003) Reactive oxygen species and matrix remodeling in diabetic kidney. J Am Soc Nephrol 14(90003):246S-249. https:// doi.org/10.1097/01.Asn.0000077411.98742.54

86. Colavitti R, Finkel T (2005) Reactive oxygen species as mediators of cellular senescence. IUBMB Life 57(4-5):277-281. https://doi. org/10.1080/15216540500091890
87. Jackson MJ (2005) Reactive oxygen species and redox-regulation of skeletal muscle adaptations to exercise. Philos Trans R Soc B 360(1464):2285-2291. https://doi.org/10.1098/rstb.2005.1773

88. Allen DG, Whitehead NP, Froehner SC (2016) Absence of dystrophin disrupts skeletal muscle signaling: roles of $\mathrm{Ca} 2+$, reactive oxygen species, and nitric oxide in the development of muscular dystrophy. Physiol Rev 96(1):253-305. https://doi.org/10.1152/ physrev.00007.2015

89. Jackson MJ (2011) Control of reactive oxygen species production in contracting skeletal muscle. Antioxid Redox Signal 15(9):2477-2486. https://doi.org/10.1089/ars.2011.3976

90. Powers SK, Duarte J, Kavazis AN, Talbert EE (2010) Reactive oxygen species are signalling molecules for skeletal muscle adaptation. Exp Physiol 95(1):1-9. https://doi.org/10.1113/expphysiol .2009 .050526

91. Labunskyy VM, Gladyshev VN (2013) Role of reactive oxygen species-mediated signaling in aging. Antioxid Redox Signal 19(12):1362-1372. https://doi.org/10.1089/ars.2012.4891

92. Vigneron A, Vousden K (2010) p53, ROS and senescence in the control of aging. Aging 2(8):471-474. https://doi.org/10.18632/ aging. 100189

93. Sanchez C (2017) Reactive oxygen species and antioxidant properties from mushrooms. Synth Syst Biotechnol 2(1):13-22. https ://doi.org/10.1016/j.synbio.2016.12.001

94. Sanocka D, Kurpisz M (2004) Reactive oxygen species and sperm cells. Reprod Biol Endocrinol 2:12w. https://doi. org/10.1186/1477-7827-2-12

95. Egea J, Fabregat I, Frapart YM, Ghezzi P, Gorlach A, Kietzmann T, Kubaichuk K, Knaus UG, Lopez MG, Olaso-Gonzalez G, Petry A, Schulz R, Vina J, Winyard P, Abbas K, Ademowo OS, Afonso CB, Andreadou I, Antelmann H, Antunes F, Aslan M, Bachschmid MM, Barbosa RM, Belousov V, Berndt C, Bernlohr D, Bertran E, Bindoli A, Bottari SP, Brito PM, Carrara G, Casas AI, Chatzi A, Chondrogianni N, Conrad M, Cooke MS, Costa JG, Cuadrado A, My-Chan Dang P, De Smet B, Debelec-Butuner B, Dias IHK, Dunn JD, Edson AJ, El Assar M, El-Benna J, Ferdinandy $P$, Fernandes AS, Fladmark KE, Forstermann U, Giniatullin R, Giricz Z, Gorbe A, Griffiths H, Hampl V, Hanf A, Herget J, Hernansanz-Agustin P, Hillion M, Huang J, Ilikay S, Jansen-Durr P, Jaquet V, Joles JA, Kalyanaraman B, Kaminskyy D, Karbaschi M, Kleanthous M, Klotz LO, Korac B, Korkmaz KS, Koziel R, Kracun D, Krause KH, Kren V, Krieg T, Laranjinha J, Lazou A, Li H, Martinez-Ruiz A, Matsui R, McBean GJ, Meredith SP, Messens J, Miguel V, Mikhed Y, Milisav I, Milkovic L, MirandaVizuete A, Mojovic M, Monsalve M, Mouthuy PA, Mulvey J, Munzel T, Muzykantov V, Nguyen ITN, Oelze M, Oliveira NG, Palmeira CM, Papaevgeniou N, Pavicevic A, Pedre B, Peyrot F, Phylactides M, Pircalabioru GG, Pitt AR, Poulsen HE, Prieto I, Rigobello MP, Robledinos-Anton N, Rodriguez-Manas L, Rolo AP, Rousset F, Ruskovska T, Saraiva N, Sasson S, Schroder K, Semen K, Seredenina T, Shakirzyanova A, Smith GL, Soldati T, Sousa BC, Spickett CM, Stancic A, Stasia MJ, Steinbrenner H, Stepanic V, Steven S, Tokatlidis K, Tuncay E, Turan B, Ursini F, Vacek J, Vajnerova O, Valentova K, Van Breusegem F, Varisli L, Veal EA, Yalcin AS, Yelisyeyeva O, Zarkovic N, Zatloukalova M, Zielonka J, Touyz RM, Papapetropoulos A, Grune T, Lamas S, Schmidt H, Di Lisa F, Daiber A (2017) European contribution to the study of ROS: a summary of the findings and prospects for the future from the COST action BM1203 (EU-ROS). Redox Biol 13:94-162. https://doi.org/10.1016/j.redox.2017.05.007

96. Casanova D, Bouzigues C, Nguyen TL, Ramodiharilafy RO, Bouzhir-Sima L, Gacoin T, Boilot JP, Tharaux PL, Alexandrou A (2009) Single europium-doped nanoparticles measure temporal pattern of reactive oxygen species production inside cells. Nat Nanotechnol 4(9):581-585. https://doi.org/10.1038/nnano .2009 .200 
97. Kalyanaraman B, Cheng G, Hardy M, Ouari O, Bennett B, Zielonka J (2018) Teaching the basics of reactive oxygen species and their relevance to cancer biology: mitochondrial reactive oxygen species detection, redox signaling, and targeted therapies. Redox Biol 15:347-362. https://doi.org/10.1016/j.redox .2017.12.012

98. Podgorska A, Burian M, Szal B (2017) Extra-cellular but extraordinarily important for cells: apoplastic reactive oxygen species metabolism. Front Plant Sci 8:1353. https://doi.org/10.3389/ fpls.2017.01353
99. Wang H, Zhang X (2017) Magnetic fields and reactive oxygen species. Int J Mol Sci 18(10):2175. https://doi.org/10.3390/ijms1 8102175

Publisher's Note Springer Nature remains neutral with regard to jurisdictional claims in published maps and institutional affiliations. 